\title{
REPRODUCTIVE NOTES ON SHREWS (FAMILY SORICIDAE) IN LOUISIANA
}

\author{
Leann Lucas ${ }^{1}$ and Justin D. Hoffman ${ }^{2,3}$
}

\begin{abstract}
Little information is known about reproduction in the 3 species of shrews in Louisiana. We examined reproductive notes from specimen records for the southern short-tailed shrew (Blarina carolinensis), least shrew (Cryptotis parva), and southeastern shrew (Sorex longirostris). Most breeding activity occurred from March to December for B. carolinensis and C. parva. Average number of embryos was 3.75 for B. carolinensis and 5.5 for C. parva. The average length of testes was $5.2 \mathrm{~mm}$ for B. carolinensis and $3.8 \mathrm{~mm}$ for C. parva. One male S. longirostris possessed a testis length of $3 \mathrm{~mm}$.
\end{abstract}

RESUMEN.-Existe poca información sobre la reproducción de las 3 especies de musarañas de Louisiana. Revisamos notas sobre reproducción referentes a los registros de especímenes de musarañas de cola corta del sur (Blarina carolinensis), musarañas diminutas (Cryptotis parva) y musarañas del sureste (Sorex longirostris). La mayor actividad reproductiva de B. carolinensis y de C. parva ocurrió entre marzo y diciembre. El número promedio de embriones fue 3.75 para B. carolinensis y 5.5 para C. parva. La longitud media de los testículos de B. carolinensis fue $5.2 \mathrm{~mm}$ y de C. parva $3.8 \mathrm{~mm}$. Un macho de Sorex longirostris tenía testículos de una longitud de $3 \mathrm{~mm}$.

There are 3 species of shrews (Family Soricidae) in Louisiana (Lowery 1974). The southern short-tailed shrew (Blarina carolinensis) is the largest shrew and occupies all regions of Louisiana except the southern portion of the state, which is dominated by saltwater marshes. The least shrew (Cryptotis parva) is a small shrew which is only absent from the extreme southeastern parishes. The southeastern shrew (Sorex longirostris) is restricted to a 6-parish region in the eastern part of the state. The Louisiana Department of Wildlife and Fisheries (LDWF) considers S. longirostris imperiled in the state because of its rarity (LDWF 2013). A fourth species, Elliot's short-tailed shrew (Blarina hylophaga), is suggested to exist in the extreme northwestern portion of Louisiana (George et al. 1981, Thompson et al. 2011). However, the identification of this species, and its resulting distribution, was based solely on morphometric analysis of the skull. Recent genetic work in Arkansas has shown that what was originally believed to be B. hylophaga in southern Arkansas (as reported by George et al. 1981 and Thompson et al. 2011) was actually B. carolinensis (Pfau et al. 2011). Based on this recent information, we felt that the presence of $B$. hylophaga in Louisiana was questionable and thus de- cided not to include it in this study. Lowery (1974) indicated that little information exists on reproduction for these species in Louisiana, and no new information has been published since that time. The objective of this research is to report on the reproductive patterns of the 3 species of shrews found in Louisiana.

We conducted an extensive search for reproductive information on shrews in Louisiana. First we visited the Museum of Natural Sciences at Louisiana State University and the W.A.K Seale Vertebrate Museum at McNeese State University. Second, we contacted all universities and colleges in Louisiana and requested any available information on each species. Finally, we did a national search on VertNet (http://www.vertnet.org/) for additional information. Reproductive data was collected from specimen voucher tags or museum catalogs (Appendix). Information regarding a specimen's reproductive condition was recorded. This included presence/absence of embryos, number of embryos, evidence of lactation, and length of testes. Any other reproductive notes associated with the specimen record were also noted.

We examined approximately 300 records of B. carolinensis from Louisiana. Of those, 19

\footnotetext{
${ }^{1}$ Harold Pearl Dripps Department of Agriculture, McNeese State University, Lake Charles, LA 70609

${ }^{2}$ Department of Biological and Health Sciences, McNeese State University, Lake Charles, LA 70609. E-mail: jhoffman@mcneese.edu

${ }^{3}$ Corresponding author
} 


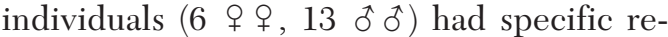
productive information associated with their specimen record. An additional 45 individuals (all females) possessed a notation of "no embryos." The average number of embryos among female B. carolinensis was $3.75 \mathrm{~mm}$ $(2-5 \mathrm{~mm})$. Four of the female shrews were pregnant and captured in different months including April, September, October, and November. The fifth and sixth females had no records of embryos present, but a note associated with the specimens indicated that they were lactating and that mammary glands were prominent. These specimens were captured in the month of April and June, respectively. Thirteen male $B$. carolinensis possessed an average testis length of $5.2 \mathrm{~mm}(3-8 \mathrm{~mm})$. The months of capture for these males included one in each of the months of February, April, June, and October. Two were captured in March and 7 were captured in November. Generally, these results support the findings of other studies on B. carolinensis reproduction. O’Farrell et al. (1977) noted that pregnancies were highest in March and September in South Carolina. The average litter sizes of B. carolinensis in Louisiana were similar to those in South Carolina (3.95; O'Farrell et al. 1977), North Carolina (4; Brimley 1923), and Florida (4; Moore 1946).

We examined approximately 350 records of C. parva from Louisiana. Seven individuals $(2$ 우; 5 ô $\widehat{0}$ ) had reproductive information associated with their specimen record. An additional 48 female specimens had a notation of "no embryos." One female possessed a litter size of 5 and was captured in early December, while the other female had a litter size of 6 and was captured in late March. One record noted a situation where 7 young were found in a nest with 2 adults in April. Five males possessed an average testis length of $3.8 \mathrm{~mm}(3-5$ $\mathrm{mm})$. Four males were captured in November and one in August. Reproduction in C. parva appears to be highly variable in different parts of the species' range (Whitaker 1974). In the northern portion of the range, reproduction is limited from March to November, but in areas farther south such as Florida and Central America, breeding may occur year-round (Hamilton 1944, Choate 1970). Our results seem to support this pattern, given that one specimen possessed a litter size of 5 and was captured in December, but it appears that most reproductive activity occurs between March and November. The number of embryos (5-6) reported from Louisiana specimens is somewhat higher than most reports from other states including Florida (2; Pournelle 1950), Texas (3-4; Davis and Joeris 1945), Kentucky (6; Welter and Sollberger 1939), Indiana (3; Whitaker 1974), and New Jersey (4; Connor 1953).

We examined 11 records of $S$. longirostris from Louisiana. One male specimen possessed a testis length of $3 \mathrm{~mm}$ and was captured in March. Currently, no published information on breeding times or litter sizes of S. longirostris exists from Louisiana. Information from other states suggests that breeding occurs between March and October and litter sizes range from 1 to 10 (Dusi 1959, Sealander 1960, Lindsay 1960, Negus and Dundee 1965, French 1980).

Our results show that shrew breeding periods run from March through December, with most activity occurring in March-April and September-November. Whether this is a bimodal pattern or the result of low sample size cannot be determined at this time. Litter sizes and breeding periods for B. carolinensis appear to be similar to other populations throughout its range. Reproductive information for C. parva from Louisiana suggests that litter sizes are higher and the breeding period is longer than for populations from northern portions of the species' range; however, more data are needed to confirm this hypothesis. Finally, information on S. longirostris reproduction in Louisiana is sorely needed. Given that this species is of conservation concern in the state, efforts should be made to gather natural history information on this species.

We sincerely thank Jacob Esselstyn, Steven Cardiff, and Laura Savage of the Louisiana State Museum of Natural Science for assisting us in gaining access to the museum collections. We thank Jonathan Dunnum from the Museum of Southwestern Biology at the University of New Mexico and Laurence Hardy from the Museum of Life Sciences at Louisiana State UniversityShreveport for providing data from specimen records. We also thank the other museum and university faculty and staff from various institutions throughout Louisiana for responding to our request for information. Finally data was collected from the University of Florida's Museum of Natural History (VertNet). 


\section{Literature Cited}

BRImLEY, C.S. 1923. Breeding dates of small mammals at Raleigh, North Carolina. Journal of Mammalogy 4:263-264.

ChOATE, J.R. 1970. Systematics and zoogeography of middle American shrews of the genus Cryptotis. University of Kansas Publications, Museum of Natural History 19:195-317.

ConNor, P.F. 1953. Notes on the mammals of a New Jersey pine barrens area. Journal of Mammalogy 34:227-235.

DaVIS, W.B., AND L. JoERIS. 1945. Notes on the life history of the little short-tailed shrew. Journal of Mammalogy 26:136-138.

Dusi, J.L. 1959. Sorex longirostris in eastern Alabama. Journal of Mammalogy 40:438-439.

French, T.W. 1980. Natural history of the southeastern shrew, Sorex longirostris Bachman. American Midland Naturalist 104:13-31.

George, S.B., J.R. Choate, and H.H. Genoways. 1981 Distribution and taxonomic status of Blarina hylophaga Elliot (Insectivora: Soricidae). Annals of Carnegie Museum 50:493-513.

Hamilton, W.J., JR. 1944. The biology of the little shorttailed shrew, Cryptotis parva. Journal of Mammalogy 25:1-7.

Lindsay, D.M. 1960. Mammals of Ripley and Jefferson Counties, Indiana. Journal of Mammalogy 41:253-262.

[LDWF] Louisiana Department of Wildifife and Fisheries. 2013. Rare animal fact sheet. [Accessed 21 July 2014]. http://www.wlf.louisiana.gov/wildlife/ rare-animals-fact-sheets
LOWERY, G.H., JR. 1974. The mammals of Louisiana and its adjacent waters. Louisiana State University Press, Baton Rouge, LA. xxiii + 565 pp.

Moore, J.C. 1946. Mammals from Welaka, Putnam County, Florida. Journal of Mammalogy 27:49-59.

Negus, N.C., And H.A. DundeE. 1965. The nest of Sorex longirostris. Journal of Mammalogy 46:495.

O'Farrel, M.J., D.W. Kaufman, J.B. Gentry, and M.H. SMITH. 1977. Reproductive patterns of some small mammals in South Carolina. Florida Naturalist 40: $76-84$.

Pfau, R.S., D.B. Sasse, M.B. Connior, and I.F. Guenther. 2011. Occurrence of Blarina brevicauda in Arkansas and notes on the distribution of Blarina carolinensis and Cryptotis parva. Journal of the Arkansas Academy of Science 65:61-66.

Pournelle, G.H. 1950. Mammals of a north Florida swamp. Journal of Mammalogy 31:310-319.

SEALANDER, J.A., JR. 1960. Some noteworthy records of Arkansas mammals. Journal of Mammalogy 41: 525-526.

Thompson, C.W., J.R. Choate, H.H. Genoways, and E.J. FInCK. 2011. Blarina hylophaga (Soricomorpha: Soricidae). Mammalian Species 43:94-103.

Welter, W.A., AND D.E. Sollberger. 1939. Notes on the mammals of Rowon and adjacent counties in eastern Kentucky. Journal of Mammalogy 20:77-81.

Whitaker, J.O., JR. 1974. Cryptotis parva. Mammalian Species 43:1-8.

Received 23 January 2015 Accepted 1 May 2015

APPENDIX. Records of Blarina carolinensis, Cryptotis parva, and Sorex longirostris examined for reproductive information, listed by species and museum. Acronyms: Museum of Natural Sciences at Louisiana State University (LSUMZ), Museum of Life Sciences at Louisiana State University-Shreveport (LSUS), W.A.K. Seale Vertebrate Museum at McNeese State University (MSC), Museum of Southwestern Biology at the University of New Mexico (MSB).

\begin{tabular}{lll}
\hline Species & Museum & Specimen numbers \\
\hline Blarina carolinensis & LSUMZ & $2313,15145,15961,21910,21912,21913,21914,21916,23963,26717,26718$ \\
& LSUS & $691,739,740,1621,1715,1735,2150$ \\
\multirow{2}{*}{ Cryptotis parva } & MSC & 9350 \\
& LSUMZ & $2474,15122,21917,21919,26721,29130$ \\
Sorex longirostris & LSUS & 1609 \\
& MSB & 45747 \\
\hline
\end{tabular}

